\title{
Підготовка шламів шліфувальних верстатів до металургійного переплаву
}

\begin{abstract}
Проаналізовано відходи металообробної промисловості з точки зору їх подальшої переробки. Встановлено відсутність ефективних методів переробки та утилізації шліфувальних шламів, та як наслідок ичього, негативний вплив на навколишнє середовище. Проаналізовано існуючі методи переробки шліфувальних шламів. Доведено доиільність застосування методу металургійного переплаву за умови спеціальної підготовки металевих шламів шліфувальних верстатів. Встановлено, щуо брикети для подальшої їх переробки повинні мати певну щуільність $i$ чистоту. Запропоновано перед використанням в металургійному переплаві шлами відмивати від МОТС (мастильно-охолоджуючих технологічних середовищах) у спеціальних розчинах за допомогою мийних машин, брикетувати та сушити.

3 метою визначення технологічних параметрів процесу брикетування иламів иліфувальних верстатів та сушки брикетів експериментально досліджено вплив тиску пресування, концентрації зв'язуючої речовини та концентрації рідини (води) на щзільність брикету. Отримано відповідні математичні залежності та побудовані графіки поверхонь. Встановлено, щзо найбільш значущчим фактором впливу на щүільність брикету є тиск пресування, менш значущим - концентрація рідини та зв'язуючої речовини. У разі збільшення концентрації води щільність брикету знижується. Рекомендовано для запобігання розсипання брикету після висушування додавати зв'язуючий елемент у кількості 3-5 \% від маси сухого шламу. Для розчинення зв'язуючого додають воду, оптимальним варіантом концентрації якої $\epsilon$ 6-8 \%. Рекомендовано технологічні параметри пресування.
\end{abstract}

Ключові слова: илами шліфувальних верстатів; брикет; пресування; щільність брикету; концентрація; зв'язуюча речовина; вода; тиск пресування.

Актуальність теми. В металообробній промисловості під час виготовлення різних виробів утворюється значна кількість металевих відходів, основними з яких є:

- лом (обрізь металів, що залишається після механічної обробки та штампування);

- висічка (частки металів, що виникають під час обробки тиском);

- стружка (металеві відходи, що залишаються після механічної обробки металів різальним інструментом);

- шлам (металеві відходи після процесу шліфування) [7, 16].

В основному усі металеві відходи підлягають подальшій переробці. Але особливу проблему становлять шлами шліфувальних верстатів (а це на сьогодення майже 4 \% від металевих відходів), які не переробляють, а вивозять на спеціальні звалища, оскільки вони є важкоруйнівним конгломератом металевих частинок із вкрапленнями абразиву i зв'язування, просоченими МОР (мастильноохолоджуючою рідиною) $[1,6]$.

Так, за даними [11], на шліфувальних лініях Луцького і Харківського підшипникових заводів генерується 3 тонни шламу в день.

На полігоні промислових відходів ПАО «Харківський підшипниковий завод» накопичена величезна кількість промислових шліфувальних шламів (табл. 1).

Таблиия 1

Кількість накопичених шліфувальних шламів на полігоні промислових відходів ПАО «Харківський підиипниковий завод» з 2014 до 2017 року, тонн [1]

\begin{tabular}{|c|c|c|}
\hline Рік & Накопичено & Фактично утворено \\
\hline 2014 & 102910,191 & 1123,0 \\
\hline 2015 & 104033,191 & 770,0 \\
\hline 2016 & 104803,191 & 584,0 \\
\hline 2017 & 105387,191 & 496,0 \\
\hline
\end{tabular}

(C) О.В. Чернишов, Д.Г. Музичка, А.І. Трикіло, В.А. Яновський, 2019 
Відсутність ефективних методів переробки та утилізації шліфувальних шламів негативно впливає на навколишнє середовище: прогресує його забруднення, спостерігається виснаження природних ресурсів, зниження стійкості біосфери, тобто погіршення екологічної ситуації взагалі. Тому все більш актуальною стає проблема утилізації шліфувальних шламів шляхом їх подальшої переробки.

Аналіз останніх досліджень та публікації, на які спирається автор. До металовмісних шламових відходів металообробного виробництва належать шлами шліфувальних, обкатних, заточувальних верстатів та ін., які утворюються при обробці конструкційних, легованих, інструментальних, швидкорізальних сталей та ін. матеріалів. Авторами [10] встановлено, що відсоток сталевих шліфувальних шламів від їх загальної кількості становить 80 \%.

Склад та властивості шламів здебільшого залежать від режимів механічної обробки та використовуваних МОР, в які входять розчини поверхнево-активних речовин 3 різноманітними функціональними домішками. Хімічний склад металевої складової шламів в основному відповідає хімічному складу оброблюваної сталі. Різниця полягає у вмісті кисню, який у шламі зазвичай складає 2$3 \%$ та може доходити до 5-6 \%. Винятком можуть бути тільки шлами на масляній МОР. Наприклад, шлами, що утворюються при шліфуванні кульок підшипників (масло МР-7, вміст кисню 1,1-1,3 \%), та шлами чавуну, в яких металева матриця захищена від окислення структурно вільним графітом (вміст кисню 0,6-0,7 \%) [9].

Проблемі утилізації шліфувальних шламів присвячений цілий ряд робіт авторів [1, 8, 6, 5, 2, 3, 4, 17] та ін.

Оскільки шліфувальні шлами є важкоруйнівним конгломератом металевих частин зі вкрапленнями абразиву (електрокорунду чи карбіду кремнію), зв’язки та МOР, то їх властивості не дозволяють використовувати для переробки методи магнітної сепарації.

Традиційним способом утилізації відходів є плавильний переділ. Однак у чистому вигляді, без спеціальної підготовки, шлами не можуть бути перероблені цим методом.

Перед використанням у металургійній промисловості шлами необхідно очистити від МОТС (мастильно-охолоджувальних технологічних середовищ). Для цього існують різні методи, найбільш розповсюдженим 3 яких $є$ миття [12, 14-16]. Сутність методу полягає у видаленні МОТС зі шламу шляхом промивання у спеціальних мийних розчинах. Після очистки зі шламів шляхом пресування отримують брикети, які у подальшому мають бути висушені, оскільки при брикетуванні для розрідження у суміш додається рідина. Допустимий вміст вологи у готовому брикеті для використання у подальшій переробці не має перевищувати 1 \%. Крім цього, для ефективного застосування у металургійному переплаві брикети повинні мати певну щільність і чистоту.

Аналіз сучасного стану досліджень переробки шламів відходів металообробної промисловості показав, що на теперішній час питання брикетування досліджено недостатньо.

Метою статті є визначення технологічних параметрів процесу брикетування шламів шліфувальних верстатів та сушки брикетів.

Викладення основного матеріалу. Дослідження процесу брикетування шламів шліфувальних верстатів проводили на лабораторному пресі моделі П6324. Для проведення експерименту було виготовлено прес-форму та штемпель. Зважування порцій шламу та брикетів проводили на електронних вагах JY-200 (ціна ділення - 0,01 г).

Відмитий від МОТС та висушений шлам шліфувальних верстатів ділили шляхом зважування на порції по 50 г. До кожної порції додавали зв'язуючий елемент, концентрація якого складала 4, 6, 8, 10 \% від маси порції висушеного шламу. Суміш шламу та зв'язуючого перемішували, добавляли воду та ще раз ретельно перемішували до однорідної густої маси. Частка води в різних порціях складала 4, 6, 8 \% від маси суміші. Отриману суміш завантажували в прес-форму і пресували під тиском 50, 100, 150, 200 МПа.

Отримані брикети зважували та висушували в електричній муфельній печі СНОЛ-1,6.2,51/9-ИЗ. Під час сушки через кожні 5 хвилин заміряли вагу брикету з метою дослідження процесу кінетики сушки. Після встановлення сталості ваги брикету він вважався висушеним. У висушених зразків заміряли геометричні параметри та розраховували їх щільність.

Результати експериментів оброблювалися методами математичної статистики за допомогою пакета програм Microsoft Office Professional Plus 2016.

Отримано математичні залежності щільності брикету $\gamma$, кг/дм³

- від тиску пресування та концентрації води:

$$
\gamma\left(P, C_{B}\right)=1,1777+0,0077 P+0,0338 C_{B}-1,5477 \cdot 10^{-5} P^{2}-0,00001 P \cdot C_{B}-0,001 \cdot C_{B}^{2},
$$

де $P$ - тиск пресування, МПа;

$C_{B}$ - концентрація рідини (води), \%;

- від концентрації води та концентрації зв'язуючого елемента:

$$
\gamma\left(C_{B}, C_{3}\right)=1,985-0,0964 C_{3}+0,0379 C_{B}+0,0049 C_{3}+0,0011 C_{3} \cdot C_{B}-0,002 C_{B}^{2},
$$

де $C_{3}$ - концентрації зв'язуючої речовини, \%;

- від тиску пресування та концентрації зв'язуючого елемента: 


$$
\gamma\left(P, C_{3}\right)=1,7059+0,049 P-0,025 C_{3}+1,2727 \cdot 10^{-6} P^{2}-0,0004 P \cdot C_{3}+0,0083 \cdot C_{3}^{2} .
$$

За отриманими залежностями (1)-(3) побудовано графіки поверхонь, представлені на рисунках 1-3 відповідно.

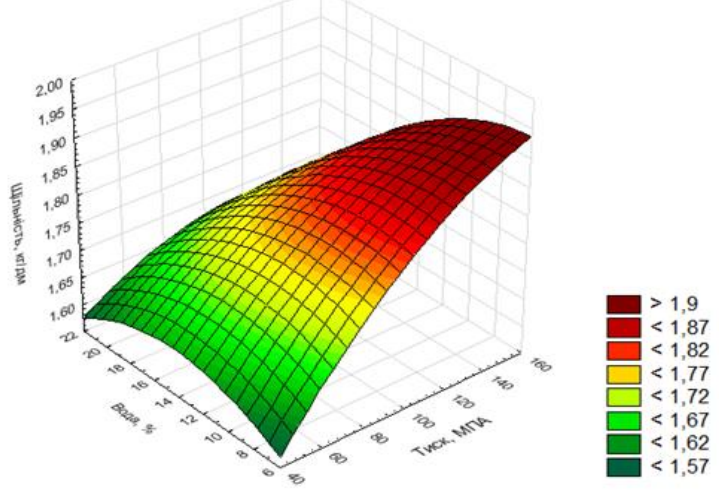

Рис. 1. Залежність щуільності брикету від тиску пресування та концентрації води

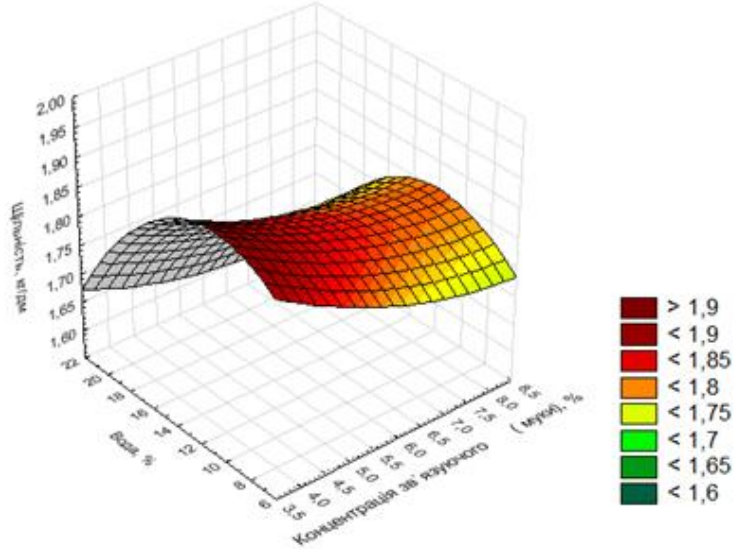

Рис. 2. Залежність щиільності брикету від концентрації води та конщентращії зв'язуючого елемента

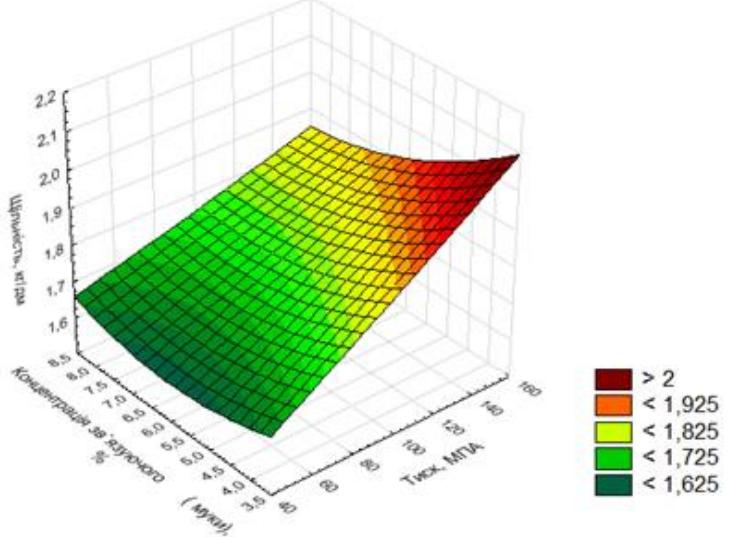

Рис. 3. Залежність щиільності брикету від тиску пресування та концентрації зв'язуючого елемента

Аналіз рисунка 1 показав, що при збільшенні тиску пресування щільність брикету збільшується. Проте необхідно враховувати, що збільшення концентрації води впливає на щільність негативно.

Великого впливу на щільність брикету концентрації води та зв’язуючого не мають (рис. 2). Для оптимальної щільності брикету велика концентрація води та зв'язуючого не потрібні. Але для того щоб брикет не розсипався, у будь-якому випадку необхідно додавати зв'язуючий елемент, змочений водою.

3 рисунка 3 видно, що чим більший тиск пресування, тим більша щільність брикету. Але знову бачимо, що при збільшенні концентрації зв'язуючого щільність брикету не збільшується.

Результати дослідження процесу кінетики сушки показали, що швидкість сушіння залежить від щільності брикетів і температури сушильного агента: чим вища щільність брикету, тим більша температура сушки необхідна (рис. 4). При низькій температурі залежність вологості у процесі сушки більш лінійна. 


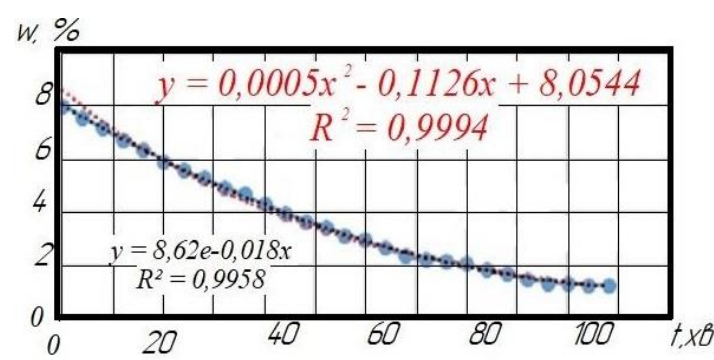

Рис. 4. Графік залежності вологості пакета від часу сушки при температурі $100^{\circ} \mathrm{C}, \gamma=1,97$ кг/дм3

Висновки та перспективи подальших досліджень. Аналіз виконаних досліджень показав, що найбільш значущим фактором впливу на щільність брикету є тиск пресування, менш значущим концентрація рідини та концентрація зв'язуючої речовини. У разі збільшення концентрації води щільність брикету знижується, оскільки суміш розріджується і при пресуванні маса «пливе». А при недостачі води зв'язуючий компонент не розчиняється повністю, що приводить до погіршення якості отриманих брикетів. Тому, оптимальним варіантом концентрації води є 6-8 \%.

Для отримання оптимальної щільності брикету підвищена концентрація води та зв'язуючого не потрібна. Але для запобігання розсипання брикету після висушування необхідно додавати зв'язуючий елемент у кількості 3-5 \% від маси сухого шламу, оскільки вода необхідна тільки для розчинення зв'язуючого (до 6-8 \%).

Отримані брикети мають хорошу щільність і можуть переплавлятися в плавильних печах. Запропоновані режими пресування можна рекомендувати при виготовленні брикетів на промисловому валковому пресі.

Для сушки пакетів великої щільності необхідно інтенсифікувати процес за рахунок продувки брикету гарячим повітрям та, крім конвекції, інтенсифікувати процес інфрачервоним випромінюванням.

\section{Список використаної літератури:}

1. Вернигора В.Д. Удосконалення екологічно безпечної технології утилізації шліфувальних шламових відходів : дис. ... канд. техн. наук : 21.06.01 / В.Д. Вернигора. - Кам’янське : Дніпровський держ. техн. ун-т, 2019. $-215 \mathrm{c}$.

2. Гальчук T.Н. Вдосконалена технологічна схема переробки шламових відходів машинобудування / T.Н. Гальчук // Вісник Хмельницького національного університету. - 2012. - № 4. - С. 26-30.

3. Гальчук T.H. Розробка технології отримання металічного порошку для виготовлення виробів машинобудівного виробництва / Т.Н. Гальчук // Міжвузівський збірник «НАУКОВІ НОТАТКИ». - Луцьк, 2012. - Вип. № 38. -С. 25-30.

4. Гальчук T.Н. Технология получения порошковых изделий из отходов машиностроения / T.Н. Гальчук // Междунар. промышленный журн. «Мир техники и технологии». - 2013. - № 3. - С. 58-61.

5. Дьяконов О.М. Шламы металлообрабатывающего производства. Ч. 1. Химический состав / О.М. Дьяконов // Литьё и металлургия. - 2010. -№ 1, 2. - С. 154-159.

6. Зозуля В.Д. Применение шлифовальных металлоабразивных отходов в порошковой металлургии / В.Д. Зозуля // Порошковая металлургия. - 1998. - № 3. - С. 95-99.

7. Кокорин B.H. Процессы переработки металлосодержащих отходов производств черной металлургии и прокатки стального листа с использованием процессов ОМД : учебное пособие / В.Н. Кокорин, Е.М. Бульжев, Е.П. Терешенок. - Ульяновск : УлГТУ, 2011.- 64 с.

8. Металлоабразивные шлифовальные отходы, методы их переработки и опыт применения в наплавочных материалах / И.П. Лентюгов, И.А. Рябиев, О.Г. Кузьменко, Ю.М. Кусков // Автоматическая сварка. - 2008. № 9. - С. 43-48.

9. Промышленный рециклинг техногенных отходов : учебное пособие / В.Н. Кокорин, А.А. Григорьев, М.В. Кокорин, О.В. Чемаева. - Ульяновск : УлГТУ, 2005. - 42 с.

10. Резание конструкционных материалов, режущие инструменты и станки / под ред. П.Г. Петрухи. - изд. 2-е, перераб. и доп. - М. : Машиностроение, 1974. - 616 с.

11. СОЖ Cimcool для подшипниковой промышленности. Electromet // Ресурсосберегающие технологии: MTT. - 2008. - № 11 (84). - С. 52-53.

12. Носков В.А. Подготовка металлической стружки в моечных машинах для ее дальнейшей переработки / B.A. Носков, А.В. Чернышиов // Металлургическая и горнорудная промышленность. - 2004. - № 6. - С. 111- 113.

13. Дослідження параметрів процесу очищення металевої стружки від МОР / О.В. Чернишов, О.О. Чернишов, Д.Г. Музичка, В.В. Третяк // Addition for proceedings XXV international conference «New leading technologies in machine building», Koblevo - Kharkov, Ukraine, september 3-8, 2017. - C. 9-11.

14. Чернышов А.В. Исследование параметров процесса очистки металлической стружки в моечной машине / A.B. Чернышов, B.A. Носков // Металлургическая и горнорудная промышленность. - 2005. - № 1. - С. 130-132.

15. Підвищення ефективності процесу очищення металевої стружки від мастильно-охолоджуючих рідин за допомогою миючих розчинів / О.В. Чернишов, Д.Г. Музичка, А.І. Трикіло, В.А. Яновський // Вісник Кременчуцького національного університету імені Михайла Остроградського. - Кременчук : КрНУ, 2018. Вип. 5 (112). - С. 103-109. 
16. Підготовка шламів шліфувальних верстатів до металургійного переплаву / О.О. Чернишов, О.В. Чернишов, A.I. Трикіло та ін. // Комплексне забезпечення якості технологічних процесів та систем : матеріали VIII міжнародної науково-практичної конференції (10-12) травня 2018 р. - Чернігів : ЧНТУ, 2018. - С. 186-187.

17. Фурс B.B. Методи утилізації металообробки / B.B. Фурс // Міжвузівський збірник «НАУКОВІ НОТАТКИ». - Луцьк, 2013. - Вип. № 42. - С. 314-318.

\section{References:}

1. Vernygora, V.D. (2019), «Udoskonalennja ekologichno bezpechnoi' tehnologii' utylizacii' shlifuval'nyh shlamovyh vidhodiv», Ph.D. Thesis, 21.06.01, Dniprovs'kyj derzh. tehn. un-t, Kam'jans'ke, 215 p.

2. Gal'chuk, T.N. (2012), «Vdoskonalena tehnologichna shema pererobky shlamovyh vidhodiv mashynobuduvannja». Visnyk Hmel'nyc'kogo nacional'nogo universytetu, No. 4, pp. 26-30.

3. Gal'chuk, T.N. (2012), «Rozrobka tehnologii' otrymannja metalichnogo poroshku dlja vygotovlennja vyrobiv mashynobudivnogo vyrobnyctva», Mizhvuzivs'kyj zbirnyk «NAUKOVI NOTATKY, Luc'k, No. 38, pp. 25-30.

4. Gal'chuk, T.N. (2013), «Tekhnologiya polucheniya poroshkovykh izdelii iz otkhodov mashinostroeniya», Mezhdunar. promyshlennyi zhurn. «Mir tekhniki i tekhnologii», No. 3, pp. 58-61.

5. D'yakonov, O.M. (2010), «Shlamyi metalloobrabatyivayuschego proizvodstva. Ch. 1. Himicheskiy sostav», Lityo $i$ metallurgiya, No. 1, 2, pp. 154-159.

6. Zozulya, V.D. (1998), «Primenenie shlifoval'nykh metalloabrazivnykh otkhodov v poroshkovoi metallurgii», Poroshkovaya metallurgiya, No. 3, pp. 95-99.

7. Kokorin, V.N., Bulyzhev, E.M. and Tereshenok, E.P. (2011), Protsessy pererabotki metallosoderzhashchikh otkhodov proizvodstv chernoi metallurgii i prokatki stal'nogo lista s ispol'zovaniem protsessov OMD, uchebnoe posobie, UlGTU, Ul'yanovsk, 64 p.

8. Lentyugov, I.P., Ryabtsev, I.A., Kuz'menko, O.G. and Kuskov, Yu.M. (2008), «Metalloabrazivnye shlifoval'nye otkhody, metody ikh pererabotki i opyt primeneniya v naplavochnykh materialakh», Avtomaticheskaya svarka, No. 9, pp. 43-48.

9. Kokorin, V.N., Grigorev, A.A., Kokorin, M.V. and Chemaeva, O.V. (2005), Promyshlennyi retsikling tekhnogennykh otkhodov, uchebnoe posobie, UlGTU, Ul'yanovsk, $42 \mathrm{p}$.

10. Petrukhi, P.G. (ed.) (1974), Rezanie konstruktsionnykh materialov, rezhushchie instrumenty i stanki, izd. 2-e, pererab. i dop, Mashinostroenie, M., 616 p.

11. «SOZh Cimcool dlya podshipnikovoi promyshlennosti. Electromet» (2008), Resursosberegayushchie tekhnologii: MTT, No. 11 (84), pp. 52-53.

12. Noskov, V.A. and Chernyshov, A.V. (2004), «Podgotovka metallicheskoi struzhki v moechnykh mashinakh dlya ee dal'neishei pererabotki», Metallurgicheskaya i gornorudnaya promyshlennost', No. 6, pp. 111-113.

13. Chernyshov, O.V., Chernyshov, O.O., Muzychka, D.G. and Tretjak, V.V. (2017), «Doslidzhennja parametriv procesu ochyshhennja metalevoi' struzhky vid MOR», Addition for proceedings HHV international conference «New leading technologies in machine building» Koblevo - Kharkov, Ukraine, september 3-8, pp. 9-11.

14. Chernyshov, A.V. and Noskov, V.A. (2005), «Issledovanie parametrov protsessa ochistki metallicheskoi struzhki v moechnoi mashine», Metallurgicheskaya i gornorudnaya promyshlennost', No. 1, pp. 130-132.

15. Chernyshov, O.V., Muzychka, D.G., Trykilo, A.I. and Janovs'kyj, V.A. (2018), «Pidvyshhennja efektyvnosti procesu ochyshhennja metalevoi' struzhky vid mastyl'no-oholodzhujuchyh ridyn za dopomogoju myjuchyh rozchyniv», Visnyk Kremenchuc'kogo nacional'nogo universytetu imeni Myhajla Ostrograds'kogo, KrNU, Kremenchuk, Issue 5 (112), pp. 103-109.

16. Chernyshov, O.O., Chernyshov, O.V., Trykilo, A.I. ta in. (2018), «Pidgotovka shlamiv shlifuval'nyh verstativ do metalurgijnogo pereplavu», Kompleksne zabezpechennja jakosti tehnologichnyh procesiv ta system, materialy VIII mizhnarodnoi' naukovo-praktychnoi' konferencii', (10-12) travnja 2018, ChNTU, Chernigiv, pp. 186-187.

17. Furs, V.V. (2013), «Metody utylizacii' metaloobrobky», Mizhvuzivs'kyj zbirnyk «NAUKOVI NOTATKY», Luc'k, No. 42, pp. 314-318.

Чернишов Олександр Васильович - старший викладач Дніпровського державного технічного університету. ORCID: https://orcid.org/0000-0001-5457-258X.

Наукові інтереси: енергоресурсозбереження.

Музичка Діана Геннадіївна - кандидат технічних наук, доцент Дніпровського державного технічного університету.

ORCID: https://orcid.org/0000-0002-2914-9672.

Наукові інтереси:

- енергоресурсозбереження.

Трикіло Алік Іванович - кандидат технічних наук, доцент Дніпровського державного технічного університету.

ORCID: https://orcid.org/0000-0002-5203-5948.

Наукові інтереси: енергоресурсозбереження.

Яновський Валерій Анатолійович - доцент Державного університету «Житомирська політехніка».

ORCID: https://orcid.org/0000-0002-1702-4282.

E-mail: gogolyan2010@gmail.com.

Наукові інтереси:

- енергоресурсозбереження. 